\title{
Effects of epidural bupivacaine, bupivacaine-butorphanol and bupivacaine-morphine on postoperative analgesia for hind limb and pelvic orthopedic operations in dogs
}

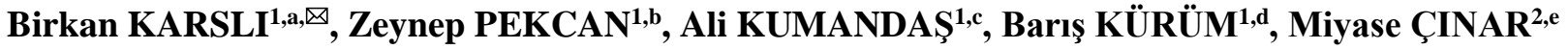 \\ ${ }^{1}$ University of Kırıkkale, Faculty of Veterinary Science, Department of Surgery, Kırıkkale; ${ }^{2}$ University of Kırıkkale, Faculty of \\ Veterinary Science, Department of Biochemistry, Kırıkkale, Turkey. \\ aORCID: 0000-0003-4208-3134; ' $\mathrm{ORCID:}$ 0000-0003-1047-5280; 'ORCID: 0000-00027679-2126; \\ ${ }^{\mathrm{d} O R C I D:}$ 0000-0002-5559-7815; ' ORCID: 0000-0003-3806-9938.
}

\author{
Corresponding author: birkankarsli@gmail.com \\ Received date: 27.01.2020 - Accepted date: 16.06.2020
}

\begin{abstract}
The aim of this study was to compare the postoperative analgesic effects of epidural bupivacaine, bupivacainebutorphanol and bupivacaine-morphine in hind limb and pelvic orthopedic operations in dogs. Three groups each containing 10 dogs were formed. Through the lumbosacral space, group B was administered bupivacaine, $1 \mathrm{mg} \mathrm{kg}^{-1}$; group BB was administered bupivacaine, $1 \mathrm{mg} \mathrm{kg}^{-1}$ and butorphanol, $0.25 \mathrm{mg} \mathrm{kg}^{-1}$; and group BM was administered bupivacaine, $1 \mathrm{mg} \mathrm{kg}^{-1}$ and morphine, $0.1 \mathrm{mg}$ $\mathrm{kg}^{-1}$. Anaesthesia was induced with diazepam $\left(0.2 \mathrm{mg} \mathrm{kg}^{-1}\right)$ and propofol $\left(5 \mathrm{mg} \mathrm{kg}^{-1}\right)$ and maintenance with isoflurane in oxygen. Pain assessment was performed with the University of Melbourne Pain Scale (UMPS) by a blinded observer. Plasma cortisol levels were measured preoperatively and postoperatively. Postoperative pain scores were significantly lower at 2 hours in the group BM, and at 8 and 12 hours in the groups $\mathrm{BB}$ and $\mathrm{BM}$ compared to the group $\mathrm{B}(\mathrm{P}=0.007)$. Group $\mathrm{BM}$ had a lower plasma cortisol level than the group $\mathrm{B}$ at 2 hours $(\mathrm{P}=0.002)$. Bupivacaine-butorphanol and bupivacaine-morphine use were shown to provide longer analgesia in the postoperative period; and the epidural administration of bupivacaine-butorphanol and bupivacaine-morphine was considered to be potentially useful in clinical practice.
\end{abstract}

Keywords: Analgesia, dog, epidural, opioid, pain assessment.

\section{Köpeklerde arka ekstremite ve pelvisin ortopedik operasyonlarında epidural bupivakain, bupivakain- butorfanol ve bupivakain-morfin uygulamasının postoperatif analjezi üzerine etkisi}

Özet: Bu çalışmanın amacı, köpeklerde arka ekstremite ve pelvisin ortopedik operasyonlarında epidural bupivakain, bupivakainbutorfanol ve bupivakain-morfin uygulamasının postoperatif analjezik etkilerinin karşılaştırılmasıdır. Her grupta 10 köpek olacak şekilde 3 farklı çalışma grubu oluşturuldu. Lumbosakral aralıktan grup B'ye bupivakain $1 \mathrm{mg} \mathrm{kg}^{-1}$; grup BB'ye bupivakain $1 \mathrm{mg} \mathrm{kg}{ }^{-1}$ ve butorfanol $0,25 \mathrm{mg} \mathrm{kg}^{-1}$; grup BM'ye ise bupivakain $1 \mathrm{mg} \mathrm{kg}^{-1}$ ve morfin $0,1 \mathrm{mg} \mathrm{kg}^{-1}$ uygulamas1 yapıld1. Anestezi indüksiyonu diazepam $\left(0,2 \mathrm{mg} \mathrm{kg}^{-1}\right)$ ve propofol $\left(5 \mathrm{mg} \mathrm{kg}^{-1}\right)$ ile yapıldıktan sonra idame izofloran ile sağlandı. Ağrının değerlendirilmesi kör gözlemci tarafından Melbourne Üniversitesi ağrı skalası (UMPS) kullanılarak yapılmıştır. Preoperatif ve postoperatif plazma kortizol seviyeleri ölçüldü. BM grubunun postoperatif 2. saatte plazma kortizol seviyesi B grubuna göre daha az olarak tespit edildi (P=0,002). Postoperatif ağrı skorları 2. saatte BM grubunda, 8. ve 12. saatte BB ve BM grubunda B grubuna göre daha az olarak tespit edildi $(\mathrm{P}=0,007)$. Çalışma sonucunda bupivakain-butorfanol ve bupivakain-morfin kullanımının postoperatif dönemde sadece bupivakain kullanımına göre daha uzun süreli analjezi sağladığı ve bupivakain-morfine göre daha düşük yan etkiye sahip olan bupivakainbutorfanolun epidural uygulamasının pratikte kullanılmasının faydalı olabileceği düşünülmüştür.

Anahtar sözcükler: Ağrı değerlendirmesi, analjezi, epidural, köpek, opioid.

\section{Introduction}

Multimodal analgesia with the combined use of opioid, local anesthetics and nonsteroidal antiinflammatory drugs (NSAIDs) is the current approach for pain management related to orthopedic surgical interventions. In veterinary practice, epidural applications of local anesthetics and opioids are widely used to maintain analgesia in pelvic and hind limb operations (17). Local anesthetics block nerve conduction, affecting both tactile and pain perception while opioids affect opioid 
receptors in the medulla spinalis to reduce or eliminate pain (1). Therefore, anesthetic-analgesic effect produced by the combined use of a local anesthetic and an opioid is greater than the use of either agent alone $(5,17)$.

Fractures may induce very severe pain, and opioids are the most suitable option for this purpose (6). All opioid analogs' analgesic efficacy and side effects depend on the ratio of the opioid receptors and their drug-binding capacity. For example, epidural use of $\mu$-receptor agonist opioids like morphine provides postoperative analgesia (16-24 hours) but may also induce side effects like pruritus, nausea, vomiting, urinary retention and respiratory depression (17). On the other hand, epidural use of butorphanol, a strong $\kappa$-receptor agonist and a weak $\mu$-receptor agonist-antagonist, produces a morphine-like analgesic effect but less side effects (15). The duration of action of epidural butorphanol is $80-240$ minutes in dogs but it lasts longer when used in combination with local anesthetics $(16,18)$.

Several subjective pain scoring methods are widely used in veterinary medicine on the interpretation of animal behavior by the observer. University of Melbourne Pain scale is also one of them which is regarded as more sensitive and more accurate than many descriptive and numerical rating scale reliable method of clinical pain assessment and has been used with success in dogs $(8,9)$. Cortisol production increase in pain and stress. Despite its limitation, serum cortisol concentration is recognized as an indicator and most objective criteria pain assessment in $\operatorname{dogs}(3,10)$.

This study aimed to investigate the analgesic effects of bupivacaine, bupivacaine-butorphanol and bupivacaine-morphine combined with bupivacaine for pelvic and hind limb orthopedic operations in dogs.

\section{Material and Methods}

This study was approved by Kırıkkale University Clinical Practice Ethics Committee (15/19) and the animal owners were informed about the study design.

Animals: The study included 30 dogs (mean age $20.67 \pm 18$, mean weight $22.43 \pm 20$ ) older than 8 months admitted to Veterinary Faculty Animal Hospital for hind limb or pelvic fractures or hind limb joint problems. According to the physical examination and biochemical test results, the dogs with abnormal blood results, coagulopathy, dermatitis on lumbosacral region were excluded from the study. The sample size of the study was calculated with the G*Power (ver. 3.1.9.2, Franz Faul, Universität Kiel, Germany) statistical analysis. The required sample size for $85 \%$ power, $\alpha=0.05$ type I error, $\beta=0.147$ and sample size was calculated as 30 .

Study protocol: The animals were randomly assigned the animals into three groups of 10 animals each, based on a computer-generated randomization schedule. The groups were nor based on gender.

Group B: $1 \mathrm{mg} \mathrm{kg}^{-1}$ bupivacaine $0.5 \%$ (Marcaine; AstraZeneca, England) and $0.22 \mathrm{ml} \mathrm{kg}^{-1}$ isotonic sodium chloride $0.9 \%$ (Isotonic NaCl; Eczacıbaşı Baxter, Turkey) were mixed.

Group BB: $1 \mathrm{mg} \mathrm{kg}^{-1}$ bupivacaine 0.5\% (Marcaine; AstraZeneca, England), $0.25 \mathrm{mg} \mathrm{kg}^{-1}$ butorphanol $1 \%$ (Butomidor; Richterpharma, Austria), and $0.22 \mathrm{ml} \mathrm{kg}^{-1}$ isotonic sodium chloride $0.9 \%$ (Isotonic $\mathrm{NaCl}$; Eczacıbaş1 Baxter, Turkey) were mixed.

Group BM: $1 \mathrm{mg} \mathrm{kg}^{-1}$ bupivacaine 0.5\% (Marcaine; AstraZeneca, England), $0.1 \mathrm{mg} \mathrm{kg} \mathrm{kg}^{-1}$ morphine $\% 1$ (Morphine; Galen İlaç, Turkey), and $0.22 \mathrm{ml} \mathrm{kg}^{-1}$ isotonic sodium chloride $0.9 \%$ (Isotonic $\mathrm{NaCl}$; Eczacıbaşı Baxter, Turkey) were mixed.

Epidural injections were carried out using a Tuohy needle (Kairos, Turkey) by the same anesthetist. During injections, the patients were sternally positioned, and the accuracy of injection site was determined using loss of resistance and hanging drop technique. Maximum epidural injection volume was determined as $12 \mathrm{ml}(9)$.

General anaesthesia procedure: Oral feeding was stopped 12 hours prior to anaesthesia but no water restriction was applied. All patients had a catheter placed to vena cephalica antebrachium for anaesthesia induction and fluid support during operation. Anaesthesia induction was performed via intravenous (IV) route using $0.2 \mathrm{mg} \mathrm{kg}^{-}$ ${ }^{1}$ diazepam (Diazem; Deva İlac, Turkey) and $5 \mathrm{mg} \mathrm{kg}^{-1}$ propofol (Propofol 2\% Fresenius; Fresenius Kabi, Austria). After endotracheal tube intubation, anaesthesia maintenance was achieved using volatile isoflurane in $100 \%$ oxygen and vaporizer set at $1.5-2.5 \%$ (Isoflurane; Adeka İlac, Netherlands), using a semicircle system (SMS company, Turkey) and a fresh gas flow of $2 \mathrm{~L}$ minute $^{-1}$. Balanced electrolyte solution (Ringesol; Vilsan, Turkey) was administered at a rate of $10 \mathrm{ml} \mathrm{kg}^{-1}$ hour-1 by IV route. Meloxicam (Maxicam; Sanovel, Turkey) $\left(0.2 \mathrm{mg} \mathrm{kg}^{-1}\right)$ was administered via IV route 5 minutes prior to the operation.

Perioperative heart rate $(\mathrm{HR})$ and rhythm, respiratory rate (RR), end-tidal $\mathrm{CO}_{2} \quad\left(\mathrm{P}_{\mathrm{E}}{ }^{\prime} \mathrm{CO}_{2}\right)$, rectal body temperature, arterial haemoglobin saturation ( $\mathrm{SpO} 2)$, and systolic (SAP), diastolic (DAP), mean arterial blood pressure (MAP) were monitored (Petaş KMA 900, Turkey) non-invasively to ensure anaesthesia safety.

In order to determine perioperative plasma cortisol levels blood samples were drawn into lithium heparin tubes before anaesthesia induction (baseline), at the end of the operation (T0), and postoperative $2^{\text {nd }}(\mathrm{T} 2), 8^{\text {th }}(\mathrm{T} 8)$ and $24^{\text {th }}$ (T24) hours. Blood samples were stored at $-70^{\circ} \mathrm{C}$ and analyzed within 6 months. Canine cortisol ELISA kit (Cusabio; Cusabio Biotech Ltd, China) was used to determine cortisol concentration by assay procedure. The 
patients were taken to the recovery room after the endotracheal tube was removed once swallowing reflex returned.

Pain assessment: Pain scores were assessed using a modified University of Melbourne Pain Scale (UMPS) 020 (9). All pain assessments and measurements were performed by the same individual and blinded observer. Pain observations were recorded before premedication in the preoperative (baseline, before premedication) and postoperative period; extubation time was considered the zero-point (T0), and at $30^{\text {th }}$ minute (T0.5) and at $1^{\text {st }}(\mathrm{T} 1)$, $2^{\text {nd }}(\mathrm{T} 2), 4^{\text {th }}(\mathrm{T} 4), 8^{\text {th }}(\mathrm{T} 8), 12^{\text {th }}(\mathrm{T} 12), 16^{\text {th }}(\mathrm{T} 16)$, and $24^{\text {th }}$ (T24) hours thereafter. The time of recovery of motor functions and first urination after epidural injection were recorded. Motor functions were assessed using positive withdrawal pedal reflex, strong resistance to flexion, anal sphincter reflex and tail motion. When any pain criterion on the scale was equal to or greater than 3 or the total pain score was equal to or greater than 9 (maximum score 20) analgesia failure was considered. In case of analgesia failure, an additional analgesic ( $1 \mathrm{mg} \mathrm{kg}^{-1}$ morphine) was administered by intramuscular route and that case was excluded.

Statistical analysis: The statistical analyses were performed using the SPSS v15 (SPSS Inc. IL, USA) statistical software. The data were tested for normality using a Shapiro-Wilk test and results showed that they did not meet the parametric test assumptions. Therefore nonparametric test was used. Age, body weight, baseline $\mathrm{HR}, \mathrm{RR}$, and rectal body temperature and intraoperative $\mathrm{HR}, \mathrm{RR}$, rectal body temperature, $\mathrm{P}_{\mathrm{E}}{ }^{\prime} \mathrm{CO}_{2}$, and $\mathrm{SpO} 2$ levels as well as the time to recovery of postoperative motor functions, time to urination, and perioperative plasma cortisol levels were compared using the KruskalWallis test and a $\mathrm{P}<0.05$ was considered statistically significant. For the UMPS levels, the nonparametric Kruskal-Wallis test was used for inter-group comparisons. Paired group comparisons were performed using the Mann-Whitney U test. Bonferroni correction was applied to paired comparisons and $\mathrm{P}<0.017$ was considered statistically significant.

\section{Results}

Our study included 21 Kangal dogs, 2 Labrador retrievers, 5 Setters, and 2 Golden retrievers. Of these animals, 14 animals underwent osteosynthesis for tibia and femur fracture; 14 excision arthroplasties for acetabulum fracture or chronic coxofemoral luxation; and 2 Paatsama procedure for rupture of anterior cruciate ligament.

One of the animals in the group BM required additional analgesia during recovery from anaesthesia and thus excluded from the study. All other animals recovered from anaesthesia without any problem.

No significant difference was noted among the animals with respect to age and weight $(\mathrm{P}>0.05)$. Baseline HR, RR, rectal body temperature and total anaesthesia time were similar among the groups $(\mathrm{P}>0.05)$ (Table 1).

No significant differences were found among the groups with respect to intraoperative $\mathrm{SpO} 2, \mathrm{P}_{\mathrm{E}}{ }^{\prime} \mathrm{CO}_{2}$ and rectal body temperature $(\mathrm{P}>0.05)$. There was a significant difference between the RR values $(\mathrm{P}<0.01)$ (Table 2$)$.

There was no significant difference between the intraoperative $\mathrm{HR}$ with respect to baseline value $(\mathrm{P}>0.05)$ (Table 3).

The comparison of perioperative plasma cortisol levels was within the reference range $\left(0-138 \mathrm{nmol} \mathrm{L}^{-1}\right)$. Inter-group analysis revealed that group BM had a significantly lower cortisol level than group $\mathrm{B}$ at postoperative second hour (T2) $(\mathrm{P}=0.002)$ (Table 4).

No significant difference was evident among the groups with regard to time of postoperative urination and recovery of motor function $(\mathrm{P}>0.05)$.

Inter-group analysis of UMPS levels at prespecified time points revealed that group BM had a significantly less severe pain score than group $\mathrm{B}$ at $\mathrm{T} 2(\mathrm{P}=0.007)$. In addition, group $\mathrm{BB}$ and $\mathrm{BM}$ had lower pain scores than group $\mathrm{B}$ at $\mathrm{T} 8$ and $\mathrm{T} 12(\mathrm{P} \leq 0.007)$. In this respect, no significant differences were found between the groups with respect to pain scores at other time points (Table 5).

Table 1. Characteristics and anaesthesia time of dogs $(n=10)$

\begin{tabular}{lcccc}
\hline \multicolumn{1}{c}{ Variable } & B & BB & BM & P-Value $^{*}$ \\
\hline Age (months) & $24.86 \pm 24$ & $22.86 \pm 24$ & $14.29 \pm 12$ & 0.18 \\
Body weight (kg) & $21.86 \pm 21$ & $22.14 \pm 20$ & $23.29 \pm 18$ & 0.98 \\
Baseline HR (beats minutes ${ }^{-1}$ ) & $111.71 \pm 120$ & $111.43 \pm 120$ & $109.43 \pm 112$ & 0.82 \\
Baseline RR (breaths minute ${ }^{-1}$ ) & $29.57 \pm 25$ & $23.71 \pm 24$ & $24.57 \pm 24$ & 0.56 \\
Baseline rectal temp. $\left({ }^{\circ} \mathrm{C}\right.$ ) & $38.78 \pm 38.7$ & $38.13 \pm 38.3$ & $38.62 \pm 38.6$ & 0.14 \\
Anaesthesia time (minutes) & $95.71 \pm 105$ & $98.71 \pm 92$ & $95.00 \pm 90$ & 0.93
\end{tabular}

Data are given as mean \pm median. B (Bupivacaine), BB (Bupivacaine-butorphanol), BM (Bupivacaine-morphine), RR (Respiration rate), HR (Heart rate). 
Table 2. Intraoperative respiration rate (RR), arterial saturation of hemoglobin $(\mathrm{SpO} 2)$, end tidal carbon dioxide $\left(\mathrm{P}_{\mathrm{E}}{ }^{\prime} \mathrm{CO}_{2}\right)$ and rectal body temperature values in dogs $(n=10)$

\begin{tabular}{lcccc}
\hline \multicolumn{1}{c}{ Variable } & B & BB & BM & $\boldsymbol{P}_{\text {-Value }}$ \\
\hline RR $($ breaths minute \\
-1) & $20.86 \pm 20^{\mathrm{a}}$ & $13.14 \pm 13^{\mathrm{b}}$ & $15.43 \pm 16^{\mathrm{b}}$ & 0.01 \\
$\mathrm{SpO} 2(\%)$ & $94.57 \pm 95$ & $93.43 \pm 93$ & $94.86 \pm 96$ & 0.48 \\
$\mathrm{PE}_{\mathrm{E}} \mathrm{CO}_{2}(\mathrm{~mm} \mathrm{Hg})$ & $40.57 \pm 41$ & $42.86 \pm 43$ & $42.57 \pm 43$ & 0.16 \\
Rectal temp. $\left({ }^{\circ} \mathrm{C}\right)$ & $37.6 \pm 37.7$ & $36.84 \pm 36.7$ & $37.38 \pm 37.4$ & 0.06 \\
\hline
\end{tabular}

$\overline{\mathrm{a}, \mathrm{b}}$ Differences between the groups denominated by different letters in the same line are significant. Data are presented as mean \pm median. B (Bupivacaine), BB (Bupivacaine-butorphanol), BM (Bupivacaine-morphine)

Table 3. Preoperative and intraoperative mean heart rate at various time points in dogs $(n=10)$

\begin{tabular}{lccc}
\hline Time & B & BB & BM \\
\hline Baseline & $111.71 \pm 120$ & $111.43 \pm 120$ & $109.43 \pm 112$ \\
T0 & $103.14 \pm 110$ & $107.29 \pm 100$ & $111.57 \pm 112$ \\
T30 & $103.71 \pm 108$ & $99.43 \pm 104$ & $112.57 \pm 115$ \\
T60 & $108.14 \pm 108$ & $101.14 \pm 102$ & $115.14 \pm 114$ \\
Extubation & $105.14 \pm 104$ & $102.71 \pm 101$ & $108.43 \pm 108$ \\
$\boldsymbol{P}$-Value* & 0.60 & 0.66 & 0.88 \\
\hline
\end{tabular}

Data are presented as mean \pm median. T0 (before incision), T30 (30 th minutes in operation), T60 (60 $0^{\text {th }}$ minutes in operation). B (Bupivacaine), BB (Bupivacaine-butorphanol), BM (Bupivacaine-morphine)

Table 4. Perioperative mean plasma cortisol concentration values $\left(\mathrm{nmol} \mathrm{L}^{-1}\right)$ at various time points $(\mathrm{n}=10)$

\begin{tabular}{lcccc}
\hline Time & B & BB & BM & P-Value* \\
\hline Baseline & $49.91 \pm 67.74$ & $49.47 \pm 50.20$ & $39.10 \pm 45.30$ & 0.87 \\
T0 & $39.01 \pm 47.44$ & $34.60 \pm 22.58$ & $26.46 \pm 31.32$ & 0.86 \\
T2 & $47.74 \pm 52.68^{\mathrm{a}}$ & $36.95 \pm 23.12^{\mathrm{ab}}$ & $18.41 \pm 17.62^{\mathrm{b}}$ & 0.002 \\
T8 & $68.35 \pm 59.86$ & $37.74 \pm 17.74$ & $32.46 \pm 36.13$ & 0.69 \\
T24 & $52.38 \pm 57.76$ & $43.56 \pm 36.64$ & $36.14 \pm 42.23$ & 0.68 \\
\hline
\end{tabular}

a, b Differences between the groups denominated by different letters in the same line are significant. Data are presented as mean \pm median. B (Bupivacaine), BB (Bupivacaine-butorphanol), BM (Bupivacaine-morphine), T0 (extubation time), T2 (postoperative $2^{\text {nd }}$ hours), T8 (postoperative $8^{\text {th }}$ hours), T24 (postoperative $24^{\text {th }}$ hours).

Table 5. Postoperative pain assessment for the University of Melbourne Pain Scale (UMPS) (range 0-20) $(n=10)$

\begin{tabular}{lcccc}
\hline Time (hours) & B & BB & BM & $P$-Value \\
\hline T0 & $0.00 \pm 1$ & $0.00 \pm 1$ & $0.00 \pm 1$ & $\mathrm{P}=1.00$ \\
T0.5 & $1 \pm 1$ & $0.00 \pm 1$ & $1 \pm 1$ & $\mathrm{P}=0.70$ \\
T1 & $1 \pm 1$ & $1 \pm 1$ & $1 \pm 1$ & $\mathrm{P}=0.25$ \\
T2 & $2 \pm 1^{\mathrm{a}}$ & $1 \pm 1^{\mathrm{ab}}$ & $1 \pm 1^{\mathrm{b}}$ & $\mathrm{P}=0.007$ \\
T4 & $3 \pm 1$ & $2 \pm 0$ & $2 \pm 1$ & $\mathrm{P} \geq 0.023$ \\
T8 & $3 \pm 1^{\mathrm{a}}$ & $2 \pm 1^{\mathrm{b}}$ & $2 \pm 1^{\mathrm{b}}$ & $\mathrm{P} \leq 0.007$ \\
T12 & $2 \pm 1^{\mathrm{b}}$ & $2 \pm 1^{\mathrm{b}}$ & $\mathrm{P} \leq 0.007$ \\
T16 & $3 \pm 1$ & $2 \pm 0$ & $\mathrm{P} \geq 0.037$ \\
T24 & $2 \pm 0$ & $2 \pm 1$ & $2 \pm 1$ & $\mathrm{P}=0.36$ \\
\hline
\end{tabular}

a, b: Differences between the groups denominated by different letters in the same line are significant. Data were presented as median \pm interquartile range. B (Bupivacaine), BB (Bupivacaine-butorphanol), BM (Bupivacaine-morphine), T0 (extubation time), T0.5 (postoperative $30^{\text {th }}$ minutes), T1 (postoperative $1^{\text {st }}$ hour), T2 (postoperative $2^{\text {nd }}$ hours), T4 (postoperative $4^{\text {th }}$ hours), T8 (postoperative $8^{\text {th }}$ hours), T12 (postoperative $12^{\text {th }}$ hours), T16 (postoperative $16^{\text {th }}$ hours), T24 (postoperative $24^{\text {th }}$ hours) 


\section{Discussion and Conclusion}

In animals, epidural injections are performed with spinal needles or Tuohy needle. The latter is specifically designed for epidural puncture and allows feeling the ligamentum flavum (10). In the present study, epidural injections were performed successfully with the hanging drop technique using a Tuohy needle. A dog in the group $\mathrm{BM}$ recovered from anaesthesia in an agitated state and was excluded from the study after administering additional analgesic with parenteral route. This was thought to have occured due to irregular distribution of the administered drug in the epidural space secondary to congenital or acquired problems affecting spinal cord, i.e. abnormal amount of epidural fat, stenosis of epidural space and to the effect of gravity (18).

Opioids are the most effective drugs for postoperative analgesia and it has been reported that epidural opioid administration had a longer duration of action than the parenteral route $(11,14)$. It is also known that the combined use of opioids with local anesthetics provide higher quality and longer analgesia (5). As before mentioned epidurally administered bupivacaine, butorphanol, and morphine exert analgesic effect through different mechanisms. Although morphine use has been shown to reduce pain intensity in fracture cases, this effect has been reported to be inadequate. Therefore, the combined use of morphine with other analgesics as part of multimodal analgesia may be more beneficial (6). Some studies have reported that when preoperative analgesia was administered, patients had less pain and also required fewer analgesic substances in the postoperative period $(10,17)$. In previous studies, it was shown that epidural butorphanol produced short analgesic effect when administered alone but had a prolonged analgesic effect when used in combination with local anesthetics (4). In the present study, we demonstrated that the use of bupivacaine alone had a shorter duration of analgesic action but the bupivacaine-butorphanol and bupivacaine-morphine combinations produced a more sustained analgesic effect. Although having a shorter duration of analgesic effect, butorphanol's longer analgesic action in the postoperative period is thought to be possibly related to the favorable effect of preemptive analgesia on postoperative pain. In line with the above data, we demonstrated that the combined use of butorphanol and bupivacaine in dogs also produced a longer analgesic effect (in current study 8-12 hours) than the use of butorphanol alone (80-240 min.) (18).

There are a limited number of studies about the epidural use of butorphanol in animals. It has been reported that after an epidural butorphanol administration, plasma butorphanol concentration was higher than cerebrospinal fluid concentration in dogs. It is thought that the reason for the low concentration of the butorphanol in cerebrospinal fluid is due to the fact that is diluted by the production of cerebrospinal fluid continuously. But it was shown that absence of sensitivity was observed in hind limbs for 3 hours after epidural administration of butorphanol. (16).

It is known that opioids are widely used for postoperative pain control in veterinary practice. However, parenteral opioid use produces side effects like sedation, bradycardia, respiratory depression, vomiting, defecation, urinary retention, pruritus and ileus (19). It has been reported that epidural opioid administration reduced the rate of opioid-induced side effects and produced a longer analgesic effect (7). In the present study the mean respiratory rate was 20 minute $^{-1}$ in the bupivacaine group but was 13 and 15 per minute in the bupivacainebutorphanol and bupivacaine-morphine groups, respectively. Considering that dogs' respiratory range under anaesthesia is 6-12 per minute (13), it was evident that the intraoperative range of respiratory rate in the present cases was out of the reference limits, suggesting an inadequate anaesthesia depth; however, as intraoperative $\mathrm{P}_{\mathrm{E}}{ }^{\prime} \mathrm{CO}_{2}$ and $\mathrm{SpO} 2$ levels as well as $\mathrm{HR}$ were within reference range, this condition was not attributed to analgesia and thus no extra analgesic was deemed necessary.

Preoperative plasma cortisol concentration being in the reference range may be considered as a sign of an animal being minimally distressed (10). It has been reported that plasma cortisol concentration is a nonspecific indicator of stress and pain in animals; several studies have specifically dealt with the effects of pain on plasma cortisol levels of dogs, but still, until better biomarkers are found about stress and pain, plasma cortisol concentrations remains important in studies about analgesia $(5,12)$. It has been reported that serum cortisol levels were lower among animals that were administered analgesics for pain control after orthopedic operations (2). Epidural morphine was used for analgesia in ovariohisterectomy operation in dogs and plasma cortisol level was found to return to normal by 6 hours postoperatively (10). The results of this study showed that plasma cortisol level at the postoperative second hour was lower in the group B compared to groups BB and BM. This was considered to be related to a delayed and longer analgesic effect of morphine.

University of Melbourne pain scale is widely used for postoperative pain assessment (2), takes into consideration an animal's general appearance, appetite, salivation status, whining, reaction to palpation in the operation site, pulse and respiratory rate with mental state, and body temperature $(2,6)$. However, some researchers have informed that fear, stress, and concerns may alter physiological variables like HR and RR considered in rating of pain. The animal's environment and season may 
also be an important factor for body temperature shifts and while rating of pain these factors should also be considered for the sake of accuracy of the results (3). Odette and Smith (9), in a study of pelvic orthopedic operations in dogs, reported that epidural bupivacaine alone produced less analgesic effect than its combined use with morphine, and this difference was statistically significant at postoperative first hour. The present study pain severity was evaluated utilized UMPS pain scale and in agreement with the above-mentioned study (9), an animal's whining, excess salivation, and mental and physical state were recorded at specified intervals during intra and postoperative periods. As a result, it was demonstrated that pain severity did not significantly differ by the second hour but animals in the bupivacainemorphine group had less severe pain at the second hour postoperatively. It was shown that pain was less severe in the groups bupivacaine-butorphanol and bupivacainemorphine at the $8^{\text {th }}$ and $12^{\text {th }}$ hours postoperatively than the group bupivacaine.

In conclusion, epidural bupivacaine, bupivacainebutorphanol, and bupivacaine- morphine administrations all were shown to provide adequate analgesia in hind limb or pelvic operations in dogs. It is noteworthy to mention that bupivacaine-butorphanol and bupivacaine-morphine combinations had more prolonged analgesic action than the stand-alone use of bupivacaine, which is regarded as a supporting point for the use of the combination. As a result, the combined use of local anesthetics and butorphanol, via epidural route was noted to be potentially more useful in clinical practice.

\section{Financial Support}

This research was supported by the Scientific Research Project Coordination Unit of Kirıkkale University (2015/126).

\section{Ethical Statement}

This study was approved by Kirikkale University Clinical Practice Ethics Committee (15/19).

\section{Conflict of Interest}

The authors declared that there is no conflict of interest.

\section{References}

1. Gaynor JS, Muir WW (2009): Handbook of Veterinary Pain Managmement (2nd ed). Mosby, USA.

2. Grisneaux E, Pibarot P, Dupuis J, et al (1999): Comparison of ketoprofen and carprofen administered prior to orthopedic surgery for control of postoperative pain in dogs. J Am Vet Med Assoc 2 215, 1105-1110.
3. Holton LL, Scott EM, Nolan AM, et al (1998): Relationship between physiological factors and clinical pain in dogs scored using $s$ numeric rating scale. J Small Anim Pract, 39, 469-474.

4. Kar P (2016): A comparative study between epidural butorphanol with bupivacaine and bupivacaine alone for intra-operative and post-operative analgesia in lower limb orthopaedic surgeries. Int J Res Med Sci, 4, 4251-4255.

5. Kona-Boun JJ, Cuvelliez S, Troncy E (2006): Evaluation of epidural administration of morphine or morphine and bupivacaine for postoperative analgesia after premedication with an opioid analgesic and orthopedic surgery in dogs. J Am Vet Med Assoc, 229, 1103-1112.

6. Mathews KA (2000): Pain assessment and general approach to management. Vet Clin North Am Small Anim Pract, 30, 729-755.

7. McMurphy R (1993): Postoperative epidural analgesia. Vet Clin North Am Small Anim Pract, 23,703-716.

8. Mich PM, Hellyer PW (2008): Objective, Categoric Methods for Assessing Pain and Analgesia. 78-109. In: JS Gaynor, WW Muir (Eds), Handbook of Veterinary Pain Management (2nd ed). Mosby, St. Louis.

9. Odette O, Smith LJ (2013): A comparison of epidural analgesia provided by bupivacaine alone, bupivacaine + morphine, or bupivacaine + dexmedetomidine for pelvic orthopedic surgery in dogs. Vet Anaesth Analg $_{2}$ 40, 527536.

10. Pekcan Z, Koc B (2010): The post-operative analgesic effects of epidurally administered morphine and transdermal fentanyl patch after ovariohysterectomy in dogs. Vet Anaesth Analg, 37, 557-565.

11. Plumb DC (2002): Butorphanol tartrate. 116-119. In: DC. Plumb (Ed), Veterinary Drug Handbook (4th ed). Iowa State Press, USA.

12. Rijnberk A, Kooistra HS (2010): Adrenals. 61-93. In: A Rijnberk, (Ed), Clinical Endocrinology of Dogs and Cats: An Illustrated Text (2nd Ed). Schlütersche, Hannover.

13. Smith LJ (2015): Normal Values for Anesthetized Patients. 119-122. In: LJ Smith (Ed), Questions and Answers in Small Animal Anaesthesia (1st ed). Wiley Blackwell, UK.

14. Smith N (2008): Butorphanol: a double-blind evaluation in postoperative patients with moderate or severe pain. Can $\mathrm{J}$ Anaesth, 21, 600-610.

15. Trim CM (1983): Cardiopulmonary effects of butorphanol tartrate in dogs. Am J Vet Res, 44,329-331

16. Troncy E, Besner GJ, Charbonneau R, et al (1996): Pharmacokinetics of epidural butorphanol in isoflurane anaesthetized dogs. J Vet Pharmacol Therap, 19, 268-273.

17. Troncy E, Junot S, Keroack S, et al (2002): Resuts of preemptive epidural administration of morphine with or without bupivacaine in dogs and cats undergoing surgery: 265 cases (1997-1999). J Am Vet Med Assoc, 221, 666672.

18. Valverde A (2008): Epidural analgesia and anaesthesia in dogs and cats. Vet Clin North Am Small Anim Pract, 38, 1205-1230.

19. Wheeler M, Oderda GM, Ashburn MA, et al (2002): Adverse events associated with postoperative opioid analgesia: a systematic review. J Pain. 3, 159-180. 